\title{
PEMBINAAN ANAK JALANAN MELALUI RUMAH SINGGAH DI SUMATERA BARAT
}

\author{
Oleh \\ Firman Firman \\ Jurusan Bimbingan dan Konseling Fakultas Ilmu Pendidikan Univ.Negeri Padang \\ Email : firman@konselor.org
}

\begin{abstract}
Abstrak
Usaha pembinaan terhadap anak jalanan yang dilaksanakan oleh pemerintah serta Lembaga Swadaya Masyarakat selama ini belum menampakkan hasil sesuai dengan target yang diharapkan. Penelitian ini bertujuan untuk mengungkapkan perlakuan yang salah terhadap anak jalanan dan peranan Rumah Singgah terhadap pembinaan anak jalanan.

Penelitian ini menggunakan pendekatan kualitatif. Informan penelitian adalah anak jalanan, pekerja social, ketua yayasan/pengurus rumah singgah serta pegawai Pemda yang terlibat dalam pemberdayaan anak jalanan. Pengumpulan data menggunakan wawancara, obsevasi dan analisis dokumen. Analisis data menggunakan pola yang dikemukan Miles dan Huberman (1992), yakni melalui kegiatan: reduksi data, penyajian data dan menarik kesimpulan/verifikasi data.

Berdasarkan hasil penelitian ditemukan bahwa anak jalanan yang terdapat di Pasar Raya Padang adalah tergolong children on the street dan children of the street serta didominasi oleh anak jalanan laki-laki. Jenis, bentuk dan pelaku perlakuan salah terhadap anak jalanan bervariatif dan kompleks. Jenis perlakuan terhadap anak jalanan terdiri dari: (1) perlakuan salah fisik berupa dipukul dan ditampar, (2) perlakuan salah mental berupa dicaci maki, dipaksa, diejek, ditipu, dipalak, dilecehkan, dituduh dan dihina, dan (3) perlakuan salah seksual berupa dielus, dipeluk dan diajak berbuat tidak senonoh. Perlakuan salah ini mereka terima dari orang tua/ keluarga dan anak jalanan senior.
\end{abstract}

\section{A. Pendahuluan}

Laju urbanisasi begitu cepat serta krisis multi dimensi yang sedang dihadapi bangsa Indonesia menimbulkan dampak cukup serius di segala bidang kehidupan masyarakat. Salah satu dampak cukup menonjol di perkotaan Sumatera Barat adalah semakin meningkatnya jumlah anak jalanan, karena perkotaan di samping berfungsi sebagai pusat perekonomian dan juga pemerintahan Daerah Tingkat II, tidak luput dari masalah anak jalanan.

Persoalan anak jalanan akan berdampak negatif secara berantai apabila tidak ditanggani secara serius. Kehidupan anak jalanan penuh dengan kekerasan serta 
berpotensi untuk tubuhnya kriminalitas dan menjadi sasaran yang efektif penyebaran penyalahgunaan narkoba, yang pada gilirannya menganggu serta merusak stabilitas kehidupan masyarakat. Di sisi lain, berdasarkan penelitian Sandora (2003) ditemukan, anak jalanan menjadi masalah bukan saja karena mereka telah melakukan kegiatan ekonomi akan tetapi karena banyak menerima perlakuan salah (Child Abuse) dari keluarga, lingkungan tempat tinggal, serta sesama anak jalanan sendiri.

Kondisi tersebut membahayakan perkembangan anak jalanan dan lingkungannya. Berdasarkan pengamatan ditemukan, anak jalanan telah melakukan prilaku menyimpang yang bisa membahayakan perkembangan mental maupun fisik mereka. Berdasarkan penelitian Saleh (Firman, 2005) mengungkapkan anak jalanan cenderung melakukan tindakan pencurian dan meminum-minuman keras, sedangkan menurut Embrio (Dinas Sosial Prop.Sumbar, 2000:2) anak jalanan banyak melakukan hubungan seks di luar nikah.

Menghadapi berbagai kondisi tersebut di atas, berbagai usaha telah dilakukan oleh pemerintah dan masyarakat demi mengatasi serta menanggulangi permasalahan anak jalanan. Usaha-usaha penanggulangan terhadap anak jalanan baik yang dilaksanakan oleh pemerintah ataupun yang masyarakat, ada yang bersifat tidak manusiawi, seperti yang telah dilaksanakan oleh pemerintah DKI Jakarta, anak jalanan di tempatkan pada sebuah rumah penampungan berjeruji besi dan dikunci dari luar yang bernama Panti Sosial Bina Karya Bangun Daya 01 Cipayung Jakarta Timur. Razia yang dilaksanakan oleh aparat kepolisian untuk menghalau pengemis termasuk anak jalanan juga merupakan tindakan yang dinilai tidak manusiawi.

Selanjutnya pola pembinaan pesantren yang dilaksanakan di Dusun Ploso Kuning, Condong Catur, Sleman, Yogyakarta, berdiri sebuah lembaga tempat anakanak jalanan mendapatkan pendidikan dan keterampilan yang berada di bawah naungan Yayasan Humana yang bekerjasama dengan Yayasan Cakra Indonesia sebagai konsultan. Tenaga pendidik dikerahkan sebanyak 10 (sepuluh) orang. Struktur yang dipakai seperti struktur sebuah perguruan tinggi yang terdiri dari rektor, dosen dan mahasiswa. Karena itulah lembaga ini dinamakan oleh anak jalanan dengan istilah Kampus Tikyan yang artinya sitik-sitik lumayan, (meskipun hasilnya sedikit tapi lumayan). 
Alternatif lain pembinaan terhadap anak jalanan yang dikelola secara swadaya oleh pihak swasta ataupun pemerintah, adalah melalui pendirian pondok pemberdayaan anak jalanan terkumpul pada suatu tempat yang dinamakan dengan istilah Rumah Singgah. Keberadaan rumah singgah dimaksudkan sebagai tempat berteduh dan memperoleh perlindungan agar dapat bertumbuh serta berkembang seperti anak lainnya.

Selama di rumah singgah berkumpulan anak jalanan dari berbagai latar belakang etnis, agama tanpa dibedakan satu sama lainnya. Melalui rumah singgah anak jalanan dapat bermain serta bercanda dengan sesama anak jalanan dan pekerja sosial. Keberadaan rumah singgah baru berkembang bersamaan dengan terjadinya krisis moneter. Pada tahap awalnya rumah singgah berfungsi untuk penangganan secara terarah terhadap anak jalanan. Pada tahap selanjutnya keberhasilan rumah singgah membina anak jalanan sangat ditentukan oleh program dan strategi yang digunakan di rumah singgah.

Berbagai potensi yang dimiliki anak jalanan dapat dimanfaatkan dalam upaya memandirikan mereka. Marnio Pudjono (Buletin JPS, 2007) menjelaskan sejumlah sikap-sikap yang terkait dengan keperibadian yang berkembang ditengah anak jalanan yang dapat dijadikan sebagai faktor positif pemberdayaan anak jalanan. Beberapa sikap tersebut adalah rasa solidaritas yang tinggi, adanya basis pemahaman agama, ekonomi dan lain sebagainya. Sikap solidaritas dan ekonomi dapat dikembangkan membangun usaha bersama yang mempunyai nilai ekonomi. Sementara sikap relgius dapat digunakan untuk pembinaan moral.

Pendampingan anak jalanan merupakan tahap yang paling penting sebagai proses awal dalam pemberdayaan. Nyadi (Bulittin Jaringan Pengamanan Sosial,2007) mengungkapkan setidaknya tedapat empat tahap yang dilewati dalam proses pendapingan di rumah singgah, yaitu ; (1) pekerja sosial (Peksos) menjalin pertemanan dengan anak jalanan di tempat mereka mangkal, (2) mengenal rumah singgah sebagai tempat berteduh untuk memperoleh perlindungan, (3) identifikasi anak jalanan tersebut, jika memiliki orang tua dan diupayakan untuk kebali kepada orang tua. Bagi anak usia sekolah diupayakan untuk kembali bersekolah, dan (4) bagi 
anak yang tidak sekolah dan berusia 14 tahun ke atas diupayakan mengikuti pendidikan latihan dengan bekal keahlian yang memadai.

Pembinaan anak jalanan di Kota Padang terdapat sebayak 24 (dua puluh empat) buah Rumah Singgah, dan 11 (sebelas) rumah singgah diantaranya mendapatkan bantuan dana dari HNSDP (health and Nutrition sector Development Programe) untuk anggaran tahun 1999/2000. Sedangkan untuk anggaran tahun 2005, pemerintah melalui dana APBN menyalurkan bantuan untuk pembinaan anak jalanan dalam rumah singgah sebanyak 12 (dua belas) rumah singgah.

Begitu banyak usaha yang telah dilakukan oleh pemerintah dan masyarakat dalam menanggulangi sarta membina anak jalanan. Akan tetapi fenomena anak jalanan makin lama makin kompleks, berdasarkan pengamatan ditemukan jumlah anak jalanan makin hari makin bertambah, perilaku anak jalanan juga semakin beragam bahkan pola kehidupan anak jalanan semakin bebas dan tidak terkontrol. Sewaktu proyek rumah singgah dicanangkan pemerintah daerah, beribu LSM/Yayasan berdiri dengan fokus kegiatan pembinaan terhadap anak. Setelah berakhirnya proyek, sebagian LSM/Yayasan yang membina rumah singgah tersebut hilang dari peredaran dan kegiatan pembinaan anak jalanan yang dibinanya terhenti serta tidak tahu hutan rimbanya.

Selama proses pembinaan anak jalanan yang dilakukan sebagian rumah singgah tidak jarang bermasalah, diantaranya : anak yang dibina tumpang tindih antar satu rumah singgah yang dibina LSM/Yayasan berdekatan. Sebagian anak-anak yang selama ini hidup secara normal dengan keluarganya turun ke jalan, dengan harapan supaya memperoleh dana proyek pembinaan anak jalanan di rumah singgah. Kondisi ini dimanfaatkan oleh sebagian LSM/Yayasan yang membina rumah singgah untuk memenuhi target jumlah anak yang ditetapkan proyek rumah singgah dari pemerintah. Kekhasan kondisi geografis, sosial budaya, ekonomi, latar belakang anak jalanan serta karakteristik anak secara pribadi kurang menjadi prioritas dalam pembinaan di rumah singgah.

Keberhasilan dana pemberdayaan anak serta orang tua di sebagian rumah singgah tidak menunjukkan hasil yang mengembirakan bagi masyarakat dalam pembinaan anak jalanan. Pola pembinaan menggunakan acuan yang seragam yang 
telah dtetapkan secara baku oleh Departemen Sosial. Keterlibatan pemuka masyarakat dalam pembinaan anak jalanan di rumah singgah, seperti : Alim Ulama, Cadiak Pandai dan Niniak Mamak kurang menjadi prioritas di Sumatera Barat. Begitu juga keterlibatan RT/RW, Lurah/Walinagari kurang terlihat memberian sumbangan dalam penguatan keluarga untuk mengatasi anak jalanan di Sumatera Barat. Perkembangan pembinaan anak jalanan yang dilakukan sebagian rumah singgah yang dikelola LSM/Yayasan kurang terpantau secara baik, karena laporan dilakukan untuk memenuhi kebutuhan proyek belaka. Pekerja sosial yang melakukan pendampingan terhadap anak jalanan kurang tersaring serta dimonitoring kinerjanya secara baik oleh masyarakat, yang pada gilirannya membuahkan hasil yang kurang memuaskan terhadap pembinaan anak jalanan di rumah singgah di Sumatera Barat.

Berdasarkan fenomena tersebut di atas, ditemukan usaha-usaha pembinaan terhadap anak jalanan belum menampakkan hasil sesuai dengan target yang diharapkan. Sehubungan dengan hal itu, menarik ditelusuri lebih lanjut melalui penelitian ini, bagaimana pembinaan anak jalanan melalui rumah singgah di Sumatera Barat. Pengungkapan pembinaan anak jalanan melalui rumah singgah di Sumatera Barat bermanfaat dalam peningkatan peranserta rumah singgah untuk dan Pemda Propinsi/Kabupaten/Kota dalam pembinaan anak jalanan.

\section{B. Metode Penelitian}

Penelitian ini menggunakan pendekatan kualitatif, yang dipilih atas pertimbangan pengungkapan gejala-gejala sosial serta menemukan makna peran rumah singgah dalam pembinaan anak jalanan. Informan penelitian adalah anak jalanan, pekerja social, Ketua Yayasan/Pengurus rumah singgah serta pegawai Pemda yang terlibat dalam pemberdayaan anak jalanan. Pengumpulan data menggunakan wawancara, obsevasi dan analisis dokumen. Analisis data menggunakan pola yang dikemukan Miles dan Huberman (2004), yakni melalui kegiatan: reduksi data, penyajian data dan menarik kesimpulan/verifikasi data. Memperkuat kesahihan data hasil temuan dan otentitas penelitian terdiri dari: (1) keterpercayaan (credibilty),(2) keteralihan (transferability), (3) dapat dipertanggungjawabkan (dependability),(4) penegasan atau kepastian (confirmability). 


\section{Hasil Penelitian dan Pembahasan}

Berdasarkan hasil penelitian dan analisis data ditemukan hal-hal sebagai berikut :

\section{Profile Anak Jalanan}

Berdasarkan analisis data dapat diklasifikasikan gambaran anak jalanan yang ada di Kota Padang sebagai berikut:

\section{a. Gambaran terhadap Diri}

1) Rasa percaya diri

Berdasarrkan data yang telah dikumpulkan ditemukan sebagian besar anak jalanan memiliki rasa percaya diri yang besar. Wujud dari rasa percaya diri dimaksud adalah adanya kepedulian dan keinginan yang terdapat di dalam diri anak jalanan untuk dapat mewujudkan cita-citanya mengubah kehidupan di masa datang.

2) Tidak rendah diri (rasa malu) terhadap lingkungan dan masyarakatnya Hal ini tercermin dari apa yang diungkapkan oleh Fery berikut ini :

"Manga lo harus malu, awak kan indak mancilok do. Dari pado bauruuru tak tantu arah elok lah mancari pitih “

(Mengapa harus malu, saya tidak mencuri. Dari pada berhura hura tak tentu arah lebih baik kerja cari duit).

Pernyataan Fery justru merupakan refleksi pemikiran yang matang dari seorang anak jalanan. Berhura-hura baginya tidak bermanfaat. Keadaan ini membuktikan bahwa anak jalanan itu mempunyai tanggung jawab yang besar terhadap dirinya dan lingkungan.

Hal senada justru lebih ditegaskan lagi oleh Yandi sebagai berikut:

"Untuak apo harus malu, justru awak bangga karano kiniko awak lah bisa mancari pitih surang, bisa mambantu adiak-adiak jo manolong nenek mambuek awak bangga",

(Untuk apa harus malu, justru saya bangga karena sekarang saya bisa mengumpulkan uang, bisa bantu adik-adik dan nenek.). 
3) Bertanggung jawab terhadap keluarga

Refleksi dari rasa tanggung jawab kepada keluarga diwujudkan dalam memberikan kontribusi ekonomi terhadap keluarga. Hal ini terlihat dari penuturan Desi berikut ini:

Sajak ayah sakik, awak baranti sakolah, ibo awak mancaliak ayahtu, makonyo awak manggaleh, untuak bantu-bantu ayah.

(Semenjak ayah sakit, saya berhenti sekolah, karena kasihan sama ayah, maka saya jualan biar bisa bantu ayah).

4) Merasa terbuang dari keluarga

Perasaan merasa terbuang dan diterlantarkan oleh keluarga juga dirasakan oleh anak jalanan, hal ini tercermin dari pengungkapan informan Yandi sebagaimana tuturannya berikut ini:

Sajak amak mati, ayah tu kawin baliak, sajak itu inyo indak pernah mancaliak awak jo adiak-adiak, apolai mambari balanjo, sadiah awak jadinyo. Makonyo awak tingga jo nenek. Ayah tu indak batangguang jawab ka anak-anaknyo. Bantuak ndak punyo anak se

(Semenjak ibu meninggal, ayah saya kawin lagi dan sejak saat itu dia tidak memperdulikan saya dan adik-adik makanya saya tinggal bersama nenek. Ayah itu orangnya tidak bertanggung jawab kepada anak-anaknya. Seperti tidak punya anak saja).

Penuturan Yandi di atas menggambarkan betapa pedihnya hidup di tinggal ibu. Karena menurutnya kematian ibunya menjadi awal bencana di dalam keluarganya. Ayahnya sudah tidak mau peduli lagi dengan anakanaknya.

Kondisi seperti ini tentu saja tidak dapat dibiarkan begitu saja, karena bagaimanapun juga keluarga sebagai salah satu kelompok sosial pertama kali dalam kehidupan manusia, adalah tempat pertama kali seseorang anak belajar dan menyatakan dirinya sebagai makhluk sosial dalam keluarganya (Gerungan 2006:182). Selain itu menurut Turner (dalam Pelita BPKS; 2008), keluarga juga merupakan unit dasar dalam 
mensosialisasikan anak dan tempat sosialisasi terus-menerus sampai ia dewasa.

Menelaah pendapat-pendapat di atas, nampaklah betapa besar peranan keluarga dalam pembentukan kepribadian anak. Dalam keluarga seseorang belajar berinteraksi dengan lingkungan, baik lingkungan alam maupun lingkungan sosial. Apa yang diperoleh anak yang menyangkut norma dan kebiasaan-kebiasaan, itu pulalah yang akan dipakainya dalam pergaulannya yang lebih luas.

Apabila hubungan anak dengan keluarganya berlangsung secara wajar dan baik, maka kemungkinan besar hubungan anak dengan masyarakat sekitarnya akan berlangsung secara baik dan wajar pula. Sebaliknya apabila hubungan anak dengan keluarganya mengalami gangguan sehingga menjadi tidak wajar dan kurang baik, maka besar kemungkinan hubungan anak dengan masyarakat sekelilingnya menjadi tidak wajar dan kurang baik pula.

Di dalam keluargalah seorang anak belajar tentang nilai dan norma yang selanjutnya akan dipakai dalam pergaulannya dengan masyarakat lingkungannya. Baik buruknya nilai atau norma yang terdapat di dalam keluarga tentulah sangat berpengaruh terhadap baik buruknya sikap anak nantinya.

\section{b. Hubungan dengan Orang Tua dan Saudara}

Data yang diperoleh memperlihatkan adanya kecenderungan karakteristik hubungan anak jalanan dengan orang tua dan keluarga yaitu: berupa hubungan yang intens, biasa, dan terputus, dan semuanya dapat dilihat dalam paparan sebagai berikut:

\section{1) Hubungan dengan Orang Tua}

Hubungan ini bisa dilihat terhadap informan Desi. Karena ayahnya sakit, maka ia dengan ikhlas memutuskan untuk berhenti sekolah demi mempertimbangkan keadaan kesulitan ekonomi keluarganya saat ini. Hal ini merupakan bukti betapa dalamnya hubungan Desi dengan keluarganya. 
a) Hubungan biasa

Hubungan yang bersifat biasa antara anak jalanan dengan orang tua maupun dengan saudaranya dapat dilihat sebagaimana paparan berikut ini;

b) Anak dengan orang tua

Hubungan bersifat biasa yang terjadi antara anak jalanan dengan orang tuanya dapat terlihat dari penuturan Ramadhan berikut ini:

"Ayah manggaleh ubek, acok pulang malam. Awak jarang basuo jo ayah. Amak manjago adiak-adiak dirumah. Awak pulangnyo yo malam-malam pulo. Jadi awak jarang basuo jo urang tuo tu”

(Ayah saya jualan obat, sering pulang malam. Saya jarang ketemu ayah. Ibu merawat adik-adik saya di rumah. Saya juga juga pulang malam hari. Jadi saya jarang jumpa ayah dan ibu).

\section{2) Sesama saudara}

Hubungan yang bersifat biasa antara anak jalanan dengan saudara-saudaranya terlihat dari penuturan Ferry Awak manggaleh rokok dari jam 14.00 s/d 21.30 WIB. Pagi awak ado di rumah, tapi adiak-adiaknyo sakolah. Jadi wakatu basuo jo adiak-adiakjarang. Paliang malam hari manjalang lalok.

(Saya jualan rokok pukul $14.00 \mathrm{~s} / \mathrm{d} 21.30 \mathrm{WIB}$. Pagi saya ada di rumah, namun saudara saya sekolah, jadi kami jarang bertemu. Paling kami bertemu malam hari menjelang tidur).

Apabila diklasifikasi hubungan anak jalanan dengan keluarga, adalah :

a) Hubungan terputus

Hubungan terputus antara anak jalanan dengan orang tua serta saudara-saudaranya juga dialami oleh anak jalanan sebagaimana paparan berikut ini.

b) Hubungan dengan orang tua 
Hubungan yang terputus antara anak jalanan dengan orang tuanya diungkapkan oleh informan Yandi berikut ini

Sajak ayah kawin baliak, ayah ndak pernah mancaliak kami anak-anaknyo. Kami ndak pernah basuo jo ayah lai. Kami indak tau baa kaba ayah tu kini ko.

(Semenjak ayah saya nikah lagi, ayah tidak pernah memperhatikan anak-anaknya sehingga kami sekarang tidak mengetahui bagaimana kabar ayah sekarang)

c) Sesama saudara

Hubungan yang terputus antara anak jalanan dengan saudarasaudaranya terlihat dari apa yang dituturkan oleh Iyal berikut ini:

Sajak awak lari dari rumah dan marantau ka Padang, awak indak pernah basarobok samo adiak-adiak, antah baalah kaba adiak awak kini tu. Waktu awak pai, adiak nan ketek baru baumua 6 bulan. Ndak tau awak baa bantuak adiak awak tu kini ko. Basuo di jalan pasti awak ndak jaleh jo bantuaknyo tu.

(Sejak saya kabur dari rumah dan pergi merantau ke Padang, saya tidak pernah jumpa dengan adik saya lagi. Bagaimana kabarnya sekarang saya tidak tahu, bahkan saya juga tidak tahu bagaimana wajah adik saya yang kecil, karena waktu saya tinggalkan masih berusia 6 bulan).

\section{3) Hubungan dengan Teman Lama dan Teman di Jalanan}

Hubungan dengan teman lama dapat dikelompokkan atas

3 bentuk, yaitu: ada dan intens, ada dan biasa, serta ada tetapi terputus. Hal ini bisa dilihat dalam uraian berikut ini:

- Ada dan intens

Hal ini dapat dilihat dari hasil pengamatan terhadap Meri, yaitu punya teman akrab, masih sering bertemu dan bermain di rumah.

- Ada dan biasa 
Terlihat dari pengamatan terhadap Ramadhan, yang punya teman akrab tetapi waktu bertemu jarang karena dia mengamen/mengemis.

- Ada tetapi terputus

Hal ini dapat dilihat dari kasus Iyal, dimana sebelum dia pindah kos dia masih sering berkirim surat dengan temannya. Namun karena jarak dan kondisi psikisnya membuat hubungan dengan teman lamanya terputus begitu saja.

Hubungan sesama anak jalanan dapat dikelompokan atas 3 bentuk yaitu : ada dan intens, ada dan biasa, dan tidak mempunyai teman. Hal ini dapat dilihat berdasarkan uraian berikut :

Ada dan intens

Hal ini dapat dilihat dari pengamatan tentang Meri, Vera, Oo, dan beberapa teman sesama anak jalanan lainnya. Hubungan ini terlihat ketika mereka berkumpul dan bercanda sambil membuat alat ngamen bagi mereka yang kehilangan alat. Dan di saat-saat lampu hijau mereka pada umumnya mengelompok sambil bersenda gurau.

Ada dan biasa

Hal ini terlihat dari pengamatan terhadap Iyal yang saling bertegur sapa dengan sesama anak jalanan yang seprofesi ketika bertemu dalam beraktivitas, namun hanya sebatas teguran/sapaan saja. Tidak kelihatan kalau dia bermain atau berkumpul bersama teman-temannya yang lain.

Tidak mempunyai teman

Hal ini dapat terlihat dari pengamatan terhadap dirinya selama beraktivitas, dimana tidak pernah kelihatan ia bergaul 
atau bercakap-cakap dengan orang ataupun anak jalanan lainnya.

\section{c. Jenis dan Bentuk Perlakuan Salah terhadap Anak Jalanan}

Perlakuan salah terhadap anak (child abuse) yang dialami anak jalanan pada dasarnya bisa dikelompokkan dalam tiga jenis perlakuan salah yaitu jenis perlakuan salah fisik, perlakuan salah mental dan perlakuan salah seksual. Ketiga jenis perlakuan salah tersebut terjadi di dalam lingkungan keluarga dan lingkungan masyarakat. Perilaku salah banyak dilakukan oleh orang tua, teman sesama anak jalanan dan anggota masyarakat pada umumnya. Masing-masing jenis perlakuan salah yang terdiri atas berbagai bentuk perlakuan dan pelakunya dapat dilihat pada tabel berikut:

Tabel 1.

Jenis dan Bentuk Perlakuan Salah terhadap anak (Child Abuse) yang Dialami Anak Jalanan.

\begin{tabular}{|c|c|c|c|c|c|c|}
\hline \multicolumn{2}{|c|}{ Oleh Orang Tua } & \multicolumn{2}{|c|}{ Oleh Teman Sesama Anjal } & \multicolumn{3}{|c|}{ Petugas dan Masyarakat } \\
\hline Fisik & Mental & Fisik & Mental & Fisik & Mental & Seksual \\
\hline Dipukul & Dipaksa & Dipukul & \begin{tabular}{|l} 
Saling \\
mengejek
\end{tabular} & Dipukul & Dilecehkan & Dielus \\
\hline Ditampar & $\begin{array}{l}\text { Tidak } \\
\text { disayang }\end{array}$ & Ditampar & Ditipu & Ditampar & Dituduh & Dipeluk \\
\hline Diikat & $\begin{array}{l}\text { Tidak } \\
\text { diperhatikan }\end{array}$ & & Dipalak & $\begin{array}{l}\text { Keserempet } \\
\text { mobil/motor }\end{array}$ & Dihina & \\
\hline $\begin{array}{l}\text { Tidak diberi } \\
\text { makan }\end{array}$ & Dimarahi & & Dipaksa & Digeledah & Dihardik & \\
\hline $\begin{array}{l}\text { Disuruh bekerja } \\
\text { keras }\end{array}$ & dihardik & & Dilecehkan & & $\begin{array}{l}\text { Dianggap } \\
\text { sampah } \\
\text { masyarakat }\end{array}$ & \\
\hline
\end{tabular}

\section{Peranan Rumah Singgah dalam Pembinaan Anak Jalanan}

Sebagai wadah yang berperan memberikan pelayanan pembinaan terhadap anak jalanan, maka rumah singgah memiliki bentuk pembinaan yang terdiri dari; (1) pola pembinaan pendidikan yang berorientasi kepada ilmu pengetahuan, (2) pola pembinaan pendidikan yang berorientasi kepada mata pencarian, dan (3) pola pembinaan pendidikan yang berorientasi kepada moral dan agama. Dengan kata lain rumah singgah bertanggungjawab dalam pembinaan 
anak jalanan. Keberhasilan pembinaan anak jalanan ditentukan oleh kemampuan dan cara rumah singgah melaksanakan tugas yang dibebankan kepadanya untuk mengasuh anak jalanan.

a. Pola pembinaan pendidikan yang berorientasi pada ilmu pengetahuan

Rumah singgah berusaha meningkatkan kepedulian terhadap ilmu pengetahuan anak jalanan. Hasil penelitian menunjukkan anak jalanan di Kota Padang relatif berpendidikan rendah dan animo mengikuti pendidikan juga lemah. Usaha rumah singgah mengatasi kendala tersebut, adalah memberikan bea siswa kepada anak jalanan yang masih sekolah. Diharapkan dengan bantuan ini banyak anak jalanan yang bisa tetap sekolah. Selain itu bantuan registrasi atau pendaftaran siswa baru juga dilaksanakan oleh rumah singgah, dengan harapan anak jalanan yang drop out bisa kembali melanjutkan sekolahnya.

Bantuan lain untuk peningkatan pendidikan anak jalanan dilakukan oleh rumah singgah dengan memberikan bantuan alat-alat sekolah, seperti bantuan buku pelajaran, bantuan alat tulis dan lain sebagainya.

b. Pola pembinaan pendidikan yang berorientasi mata pencarian

Untuk pendidikan yang berorientasi pada mata pencarian rumah singgah memberi kesempatan kepada anak jalanan untuk menetapkan jenis latihan keterampilan yang ingin diikuti dalam rangka menunjang aktivitas sehari-hari.

Selain itu penambahan modal usaha juga dimaksudkan sebagai pembinaan yang berorientasi pada mata pencarian. Anak jalanan mendapatkan tambahan modal usaha, diharapkan dengan modal yang lumayan, usaha dapat berjalan dengan baik, dan dapat meraih keuntungan yang maksimal, sehingga anak jalanan dapat hidup mandiri.

c. Pola pembinaan pendidikan yang berorientasi pada moral dan agama

Di rumah singgah diciptakan suasana kekeluargaan, dengan demikian anak merasa berasa dalam sebuah keluarga. Untuk itu anak di ajarkan tentang 
etika dan sopan santun. Selain itu nilai-nilai agama juga ditanamkan kepada diri anak, sehingga nantinya anak menjadi orang dewasa yang bertanggungjawab baik terhadap dirinya maupun keluarga dan lingkungannya.

Untuk menunjang program pembinaan rohani ini, rumah singgah mempersiapkan sarana dan prasarana dalam menjalankan ibadah masingmasing.

d. Pemberian Beasiswa

Pemberian beasiswa bertujuan untuk membantu anak jalanan agar tidak putus sekolah, atau bahkan jika memungkinkan anak jalanan yang putus sekolah dapat kembali ke sekolah serta untuk meningkatkan prestasi belajar anak. Dengan demikian anak termotivasi untuk belajar dan melanjutkan sekolah.

Beasiswa diberikan selama 1 (satu) tahun yang akan dibayarkan ke sekolah Anak Jalanan setiap bulannya dan dipergunakan untuk keperluan sekolah. Beasiswa dapat dihentikan jika Anak Jalanan meninggal dunia, atau berhenti sekolah atau Anak Jalanan juga menerima beasiswa dari sumber lainnya.

Beasiswa diberikan kepada Anak Jalanan yang bisa di jangkau oleh Pekerja Sosial yang tentu saja masih masih sekolah di SD, SLTP dan SLTA serta kepada Anak Jalanan yang putus sekolah tetapi mempunyai kemungkinan untuk kembali sekolah.

Pemberian beasiswa dilaksanakan oleh Pekerja Sosial dengan kegiatan tutorial untuk menjaga agar Anak Jalanan dapat memanfaatkan beasiswa yang diterimanya dengan benar dan dapat meningkatkan prestasi belajarnya. Kegiatan tutorial dilaksanakan di Rumah Singgah, kegiatan kunjungan rumah serta kunjungan ke sekolah Anak Jalanan penerima beasiswa. Selain itu pemberian beasiswa diberikan pada awal tahun ajaran yang kemudian diberikan setiap awal bulannya. 
Pemberian beasiswa dimaksudkan sebagai salah satu bentuk pembinaan yang berorientasi pada bidang pendidikan. Anak jalanan yang masih duduk di bangku sekolah diupayakan untuk dapat terus melanjutkan pendidikannya, begitu juga dengan anak jalanan yang sudah berhenti sekolah diupayakan untuk dapat kembali ke bangku sekolah tentu saja bagi anak jalanan yang berkemauan untuk melanjutkan sekolahnya kembali.

e. Latihan Keterampilan

Latihan keterampilan diberikan dengan tujuan membekali Anak Jalanan dengan keterampilan tertentu agar anak siap bekerja serta mendidik Anak Jalanan menjadi warga masyarakat yang produktif. Sasaran dari pada pemberian latihan keterampilan adalah Anak Jalanan yang sudah putus sekolah dan sudah tidak mau sekolah lagi, serta Anak Jalanan yang berusia 15 - 18 tahun dan sudah tidak memungkinkan lagi untuk masuk sekolah serta bisa membaca dan menulis sekaligus mempunyai niat atau keinginan terhadap suatu jenis keterampilan.

Latihan keterampilan diberikan kepada anak dalam satu angkatan/paket dan besarnya dana untuk 1 paket adalah sebanyak Rp 450.000 untuk setiap anak. Dana tersebut digunakan untuk biaya kursus, dan jika ada kelebihan dana dapat dipergunakan untuk membeli kebutuhan bahan latihan sesuai dengan latihan yang dipilih anak berdasarkan minat dan bakat yang dimilikinya. Adapun bentuk keterampilan yang diikuti oleh anak jalanan yaitu berupa keterampilan montir, perbengkelan, menjahit dan membordir.

\section{f. Registrasi}

Registrasi dilaksanakan dengan tujuan mendaftarkan sekolah agar anak jalanan dapat memperoleh kesempatan sekolah kembali atau dapat melanjutkan sekolahnya ke tingkat yang lebih tinggi.Registrasi dilaksanakan pada awal tahun ajaran baru dengan cara mendaftarkan anak jalanan ke sekolah serta memberikan kebutuhan sekolahnya. 


\section{g. Bantuan Makanan}

Tujuan pemberian bantuan makanan pada anak jalanan adalah untuk mempertahankan dan meningkatkan status kesehatan dan gizi anak jalanan yang terancam turun kerena menurunnya daya beli anak atau orang tuanya.

Pelaksanaan pemberian bantuan makanan ini diberikan kepada anak jalanan murni yang tidak tinggal dengan orang tuanya lagi serta anak jalanan yang status kesehatan dan gizinya kurang baik. Bantuan makanan ini diberikan selama 1 tahun dengan besarnya nilai bantuan makanan adalah $\mathrm{Rp}$ 5.000/anak/hari dengan ketentuan menu makanan harus memenuhi standar kesehatan dan gizi.

Namun, banyak Rumah Singgah yang merasa kewalahan untuk dapat memberikan bantuan makanan bagi anak jalanan, hal ini dikarenakan, dana yang tersedia untuk bantuan makanan ini sangat minim. Rumah Singgah tidak mempunyai kemampuan untuk memberikan bantuan makanan bagi seluruh anak jalanan yang dibina, untuk itu Rumah Singgah berusaha untuk tetap memberikan bantuan makanan, dengan cara mengurangi anggaran per orangnya, sehingga kalau dalam anggaran bantuan makanan bernilai Rp 5.000/anak untuk 20 orang anak (berjumlah sebanyak Rp. 100.000), maka dengan menganggarkan per anak sebanyak Rp 4.000. maka jumlah anak jalanan yang mendapat bantuan makan adalah sebanyak 25 orang anak.

Dengan demikian jumlah anak jalanan yang mendapat bantuan makanan bertambah jumlahnya, tentu saja hal ini semakin memberikan sedikit kemudahan bagi Rumah Singgah untuk mencarikan tambahan makanan bagi anak jalanan lainnya. Hal lain yang sering dilakukan oleh Rumah Singgah singgah dalam pemberian bantuan makanan bagi anak jalanan adalah mengajak masyarakat untuk berpartisipasi.

h. Pemberian modal usaha kepada orang tua

Pemberian bantuan modal usaha kepada orang tua anak jalanan bertujuan memberikan bantuan tambahan modal usaha bagi orang tua binaan 
yang sudah mempunyai usaha dan keterampilan untuk menambah penghasilan.

Bantuan modal usaha diberikan kepada orang tua anak jalanan berupa peralatan dan bahan yang dibutuhkan sesuai dengan jenis usaha yang dilakukan.Melalui bantuan modal usaha ini, diharapkan orang tua anak jalanan memiliki usaha yang mapan sehingga dapat membiaya hidup keluarganya, dengan demikian anak tidak perlu turun kejalan mencari tambahan biaya hidup.

Selama melaksanakan pembinaan dan pemberdayaan terhadap anak jalanan di Kota Padang, beberapa hambatan ditemui oleh Rumah Singgah selaku wadah yang memberikan pelayanan pembinaan terhadap Anak Jalannan. Adapun hambatan-hambatan tersebut adalah berupa:

a. Sulitnya mencari tenaga pekerja sosial yang profesional

Dalam pembinaan anak jalanan dibutuhkan tenaga pekerja sosial yang profesional. Untuk menempatkan seorang atau lebih pekerja sosial di Rumah Singgah sangatlah sulit, karena hal ini dipengaruhi oleh beberapa hal, yaitu : (1) jumlah pekerja sosial yang profesional di Kota padang sangat terbatas, (2) tugas dan tanggung jawab seorang pekerja sosial sangat berat, salah satunya sanggub bekerja selama 24 jam. Walaupun pada realitanya tidak semua pekerja sosial sanggub bekerja selama 24 jam, akan tetapi paling tidak pekerja sosial tidak mempunyai jam kerja seperti jam kantoran. Kapanpun dibutuhkan, setiap pekerja sosial harus siap dalam tugasnya, (3) minimnya tunjangan hidup bagi seorang pekerja sosial, yaitu sebesar Rp. 400.000,00 per bulannya, (4) enggannya masyarakat berbaur dengan anak jalanan, hal ini dikarenakan masih banyaknya masyarakat yang berpandangan negatif terhadap anak jalanan. (5) besarnya resiko menjadi seorang pekerja sosial pada rumah singgah. Hal ini dimungkinkan karena masih banyak orang tua anak jalanan yang marah ketika anaknya diajak bergabung dengan rumah singgah, karena dengan bergabungnya anak jalanan dengan rumah singgah pendapatan 
anak akan berkurang, secara otomatis akan mengurangi penghasilan orang tua yang semata-mata mengharapkan dari anaknya. Biasanya orang tua yang marah adalah orang tua yang suka mengeksploitasi anaknya ke jalanan.

b. Dana pengelolaan Rumah Singgah yang terbatas

Hal ini bisa dilihat dari anggaran yang diberikan pada rumah singgah. Kalau melihat kepada besarnya anggaran yang diberikan pada rumah singgah dibandingkan dengan jumlah anak yang dibina, sangatlah $\operatorname{minim}$.

c. Kurangnya partisipasi masyarakat dalam pembinaan Anak Jalanan

Hal ini dimungkinkan karena masih banyaknya sikap antipati masyarakat terhadap Rumah Singgah serta terhadap anak jalanan itu sendiri. Masih banyak masyarakat yang kurang percaya dengan keberadaan rumah singgah. Kondisi ini terjadi karena pernah ada rumah singgah y menyelewengkan dana bantuan anak jalanan, sehingga animo masyarakat terhadap rumah singgah menjadi buruk. Selain itu sikap dan tingkah laku anak jalanan yang tidak baik juga membuat masyarakat tidak simpati.

Berhubungan dengan kondisi tersebut di atas, masyarakat sebenarnya belum mempunyai cukup pengetahuan tentang anak jalanan. Kalau anak jalanan bersikap dan bertingkah laku tidak sesuai dengan norma yang berlaku, justru hal itulah yang seharusnya menjadi tanggung jawab kita semua untuk dapat memberikan pembinaan kepada mereka, bukan sebaliknya kita menghindar atau malah mendiskriminasikan mereka dari lingkungan.

d. Salah persepsi sebahagian masyarakat bahkan pemerintah sendiri terhadap Rumah Singgah 
Pada umumnya masyarakat berpendapat bahwa makin banyaknya jumlah anak jalanan yang beraktivitas menandakan ketidakberhasilan rumah singgah dalam melakukan pembinaan. Kemudian tingkah laku anak jalanan yang dari hari kehari semakin tidak sopan juga dijadikan tolak ukur keberhasilan rumah singgah.

Persepsi masyarakat terhadap peran rumah singgah itu sendiri sebenar tidak salah, akan tetapi masyarakat kurang memberikan pandangan yang luas dalam menjadikan tolak ukur keberhasilan rumah singgah dalam pemberian pembinaan. Bagi masyarakat, jika jumlah anak jalanan semakin berkurang, dan tingkah laku mereka sesuai dengan norma yang berlaku, maka disanalah rumah singgah dikatakan berhasil. Akan tetapi masyarakat tidak melihat kondisi ini secara luas.

Kalau kita perhatikan dengan seksama, maka anak jalanan yang dari hari kehari semakin bertambah, bukan berarti kegagalan rumah singgah dalam pemberian pembinaan, akan tetapi arus urbanisasi yang memang cukup tinggi terjadi. Anak jalanan yang berada di Kota Padang pada saat ini banyak yang berasal dari luar daerah bahkan berasal dari luar propinsi.

Di samping itu, pembinaan terhadap anak jalanan, telah banyak hal yang telah dilakukan oleh pemerintah daerah, antara lain:

a. Dukungan pemda terhadap rumah singgah. Hal ini tampak dalam anggaran yang diberikan bagi rumah singgah.

b. Selain itu pemda juga sering mengadakan berbagai kompetensi bagi anak jalanan. Hal ini dimaksudkan agar anak jalanan mempunyai motivasi diri yang kuat dan merasa tidak rendah diri.

Pada umumnya pelaksanaan pembinaan terhadap Anak Jalanan dilaksanakan berdasarkan kepada petunjuk teknis pelaksanaan pembinaan Anak Jalanan Departemen Sosial RI. Namun pelaksanaanya di lapangan selalu disesuaikan dengan kondisi pada saat tertentu. Dengan demikian bentuk kegiatan pembinaan terhadap anak jalanan yang dilaksanakan oleh 
Rumah Singgah di Kota Padang memiliki variasi tersendiri yang disesuaikan dengan kebutuhan serta kemampuan Rumah Singgah sebagai wadah penyelenggara pembinaan.

\section{Kesimpulan dan Rekomendasi.}

\section{Kesimpulan}

Dari penelitian yang telah dilakukan diketahui bahwa anak jalanan yang terdapat di Pasar Raya Padang adalah tergolong children on the street dan children of the street serta didominasi oleh anak jalanan laki-laki. Jenis, bentuk dan pelaku perlakuan salah terhadap anak jalanan bervariatif dan kompleks. Jenis perlakuan terhadap anak jalanan terdiri dari: (1) perlakuan salah fisik berupa dipukul dan ditampar, (2) perlakuan salah mental berupa dicaci maki, dipaksa, diejek, ditipu, dipalak, dilecehkan, dituduh dan dihina, dan (3) perlakuan salah seksual berupa dielus, dipeluk dan diajak berbuat tidak senonoh. Perlakuan salah ini mereka terima dari orang tua/ keluarga dan anak jalanan senior.

Masyarakat menganggap bahwa anak jalanan merupakan anggota masyarakat kelas bawah yang harus disingkirkan dari kehidupan. Akibatnya mereka sebagai anak jalanan terkadang harus menerima perlakuan salah baik fisik maupun mental dari masyarakat. Perlakuan salah mental yang datang dari masyarakat seperti caci maki, hinaan, cemoohan dan lain sebagainya yang sifatnya menjatuhkan harga diri anak jalanan sebagian besar dirasakan oleh anak jalanan. Sedangkan perlakuan salah fisik yang datang dari masyarakat seperti pemukulan, penendangan dan terkadang pelemparan karena dianggap sebagai seorang pencuri/pencopet yang akan beraksi juga sering dialami oleh anak jalanan. Padahal anak jalanan melakukan kegiatan ini karena didorong oleh kebutuhan ekonomi keluarga yang kurang memadai.

Perlakuan salah terhadap anak (child abuse), khususnya anak jalanan bisa terjadi di mana saja, kapan saja dan bisa dilakukan oleh siapa saja, baik yang dilakukan oleh orang-orang terdekat seperti orang tua, teman bermain, atau bahkan dilakukan oleh orang-orang tak dikenal seperti preman pasar ataupun anak 
jalanan senior dan petugas masyarakat. Perlakuan salah bisa terjadi di rumah/keluarga, di lingkungan anak jalanan beraktivitas dan di lingkungan tempat tinggal.

Kondisi sosial budaya dan ekonomi mendorong terjadinya perlakuan salah terhadap anak (child abuse) khususnya anak jalanan. Hal ini sebenarnya merupakan cerminan bergesernya norma yang terdapat di dalam kehidupan masyarakat Kota Padang serta bukti mulai lunturnya pemahaman nilai-nilai budaya yang ada di dalam kehidupan masyarakat.

\section{Rekomendasi}

Berdasarkan hasil penelitian dapat dikemukakan rekomendasi sebagai berikut :

1. Sebagian besar anak jalanan ditemukan bersal dari keluarga broken home, miskin dan orang tua kurang dapat menjalankan tugas dan kewajibannya. Departeman Agama, Dinas social dan Binsospora dirasa perlu mengembangkan konseling perkawinan sebagai persyaratan utama bagi calon penganting sebelum melaksanakan pernikahan.

2. Lembaga Sosial dan Keagaam yang ada, seperti: Karang Taruna, Remaja Mesjid serta Majlis Taklim dan sejenisnya kurang dimanfaatkan untuk memperkuat kehidupan berkeluarga dalam mengantisipasi meningkatnya perceraian dan anak jalanan. Binsospora, Departemen Agama dan Dinas Sosial dirasa perlu mengembangkan konseling keluarga serta penyuluhan lainnya

3. Perlindungan dan pendidikan yang sudah disediakan rumah singgah yang dilaksanakan Lembaga Sosial Masyarakat (LSM) cenderung kurang dimanfaatkan oleh sebagian besar anak jalanan. Dinas Sosial dirasa perlu berkoordinasi dengan rumah singgah menyusun program pembinaan sesuai dengan kebutuhan dan karakteristik anak jalanan pada masing-masing lokasi dan daerah.---- Dinas social seakan-akan hanya pemeriksa, hendaknya dalampembuatan program RS diundang. 
4. Pembinaan yang dilaksanakan oleh rumah singgah terhadap anak jalanan sebagian kurang mengenai sasaran yang diharapkan. Dinas social perlu mengevaluasi sistem penseleksiaan, program pembinaan serta monitoring.

5. Pembinaan anak jalanan melalui rumah singgah ditemukan memisahkan anak jalanan dari masyararakat dimana mereka berdomisili. Kondisi ini tidak jarang menyebakan meningkatnya jumlah anak turun ke jalan. Dinas social, Binsospora, BPM serta Biro Pemerintahan Nagari dirasa perlu mengembangkan pembinaan anak jalanan berbasis Nagari/Lurah, Jorong/RW/RT, melalui program dan sistim pemberdayaan masyarakat.

6. Dalam rangka peningkatan perlindungan terhadap anak jalanan dari berbagai bentuk perlakuan salah perlu adanya upaya-upaya pendekatan lain terhadap keluarga dan masyarakat. Pengelola rumah singgah perlu mempertimbangkan penerapan strategi pengembalian anak kepada keluarga dan mencegah anak-anak yang masih tinggal dengan orang tua untuk turun ke jalanan. Hal ini dapat dilakukan dengan memperkuat fungsi keluarga, meningkatkan pendapatan keluarga seperti bantuan modal usaha produktif dan pendayagunaan potensi masyarakat. Anak-anak dibantu agar mendapatkan pendidikan formal maupun pendidikan non formal, pemenuhan kebutuhan dasar, pengisian waktu luang dan lain-lain sehingga mampu mengalihkan perhatian anak dari jalanan.

7. Untuk dapat mengurangi serta menghilangkan bentuk dan jenis perlakuan salah terhadap anak jalanan dirasa perlu adanya sosialisasi tentang hak-hak anak baik bagi orang tua maupun oleh masyarakat sehingga masyarakat dan orang tua bisa menempatkan anak pada posisi yang sepantasnya bagi anak.

8. Sulit mencari tenaga kerja pekerja social yang professional, persyratan akademik, pendidikan,penseleksian. Pekerja social yang ada tidak mau bekerja, fasilitas yang diberikans angat minim

9. Dana terbatas--- ketika proyek ada semua RS mengajukan kegiatan. RS tidak ada dana yang mantap untuk kegiatan ini, baiay pembinaan sangat besar.

10. Enggan anak jalanan untuk mampir ke rumah singgah--- karena persepsi orang tua bahwa RS melarang untuk bekerja, bejara adalah untuk hidup, nilai anak. Pembinaan yang diberikan tidak dapat dilakukan . 


\section{DAFTAR KEPUSTAKAAN}

Afrizal dalam Laporan hasil pemetaan dan survei anak jalanan di Kota Padang. (1999). Kanwil Depsos Sumbar dan PKPM Unika Atmajaya.

Baihaqi, MIF. (1998). Anak Indonesia teraniaya. Bandung: Remaja Rosdakarya.

Bogdan, Robert dan Taylor, Steven J. (2007). Kualitatif: dasar-dasar penelitian (alih bahasa: A. Khozin Fandi). Surabaya: Usaha Nasional.

Data Informasi Anak, Yayasan Anak Indonesia dan Private Agency Collaborating Together. (2004). Penelitian mengenai anak jalanan di Jakarta; profil, kebijakan dan program. Jakarta.

Faisal, Sanafiah. (2005). Format-format penelitian sosial. Jakarta: Rajawali Press.

. (2000). Penelitian kualitatif dasar-dasar dan aplikasi. Malang: Yayasan Asih Asah Asuh.

Fatimah, Nyayu. (2001). Anak jalanan: Fenomena sosial perkotaan. Makalah pada simposium dan lokakarya internasional II di Padang. Tanggal 18-21 Juli 2001.

Gautama, Candra. (2007). Konvensi hak anak. Jakarta: Lembaga Studi Pers \& Pembangunan.

Ishardjiati, Eka. Anak jalanan dan penanggulangannya melalui rumah singgah. Dinamika sosial. Vol 72. 1999. Kanwil Departemen Sosial Propinsi Sumatera Barat.

Irwanto, dkk. (2005). Pekerja anak di tiga kota besar: Jakarta, Surabaya, Medan. Jakarta: Pusat Penelitian UNIKA Atmajaya.

Joni, Muhammad dan Tanamas. (2005). Aspek hukum perlindungan anak dalam perspektif konvensi hak anak. Bandung : Citra Adityabakti.

Julianto, Irwan. Anak jalanan, seks dan “ngelem”. Bisnis Indonesia. 2 September 2006. 
Kanwil Departemen Sosial Propinsi Sumatera Barat. (1999). Laporan penelitian pemetaan dan survei sosial anak jalanan di Kota Padang.

Karnoji, SP. Penanganan anak jalanan butuh kekhasan. Haluan. Sabtu. 2 Juni 2001.

Kartono, Kartini. (2000). Patologi sosial I. Jakarta: Rajawali Press.

Koentjaraningrat. (2007). Pengantar antropologi pokok-pokok etnografi II. Jakarta: Rineka Cipta.

Lyncoln, Yvonna and Guba, Egar G. (2001). Naturalistic inquiry. Beverly Hills Sage Publications.

Media Informasi Penelitian Kesejahteraan Sosial No. 156. (2007). Balai Besar Penelitian dan Pengembangan Pelayanan Kesejahteraan Sosial. Yogyakarta.

Moleong, Lexy. (2007). Metodologi penelitian kualitatif. Bandung: Remaja Rosdakarya.

Muhadjir, Noeng. (2007). Metodologi penelitian kualitatif. Yogyakarta: Rake Sarasin.

Redaksi. Penanganan anak jalanan harus manusiawi. Republika. Sabtu 7 November 1998.

Sandora, Lisna (2003). Tesis, Perlakuan Salah yang dialami Anak Jalanan di Kota Padang. UNP. Padang

Spradley, James P. (2000). Participant observation. New York: Holt. Rinehart and Winston.

Sutaat. Studi kasus anak nakal pada pran Wisma Handayani Jakarta. Media Informatika No. 33. 1993. hal. 10-28. Jakarta: Badan Penelitian dan Pengembangan Sosial, Depsos.

Tamrizal Dt. Gadang. Populasi anak jalanan di Kota Padang telah meningkat. Haluan. Sabtu. 30 Januari 2003.

Tunggal, Hadi Setia. (2000). Konvensi hak-hak anak (convention on the right of the child). Jakarta: Harvarindo.

Unicef. (1989). Convention on the rights of the child. New York.

Yusuf, A. Muri. (2000). Metode penelitian, dasar-dasar penyelidikan ilmiah. Padang: Universitas Negeri Padang.

Zulkifli. (2000). Psikologi perkembangan. Bandung: Remaja Rosdakarya.

Welly, Farida. Pola Pembinaan Anak Jalanan; Studi Kasus pada Rumah Singgah Srikandi Kota Padang. Humanus. Vol. V. No. 1 Th. 2002 
